UDC 338.2(476)+316.42(476)

JEL classification: H10, J58, P35, Z13

\title{
STRUCTURAL STABILITY AND SOCIO-ECONOMIC SECURITY OF THE HIERARCHICAL SYSTEM
}

\author{
CShvaiba D., Ph.D., ORCID: 0000-0001-6783-9765, \\ Minsk regional organization of the Belarusian Trade Union of workers of chemical, \\ mining and oil industries; Belarus Belarusian national technical University, \\ Minsk,Belarus,shvabia@tut.by
}

\section{СТРУКТУРНАЯ УСТОЙЧИВОСТЬ И СОЦИАЛЬНО-ЭКОНОМИЧЕСКАЯ ЗАЩИЩЕННОСТЬ ИЕРАРХИЧЕСКОЙ СИСТЕМЫ}

\author{
СШвайба Д. Н., канд. экон. наук, ORCID: 0000-0001-6783-9765, \\ Минская областная организаџия Белорусского профсоюза работников химической, \\ горной и нефтяной отраслей промышленности; \\ Белорусский национальный технический университе, г. Минск, Беларусь, shvabia@tut.by
}

Abstract. The financial and economic macro-system mixes different hierarchical structures: functional, sectoral, territorial. Its hierarchical structure has the ability to be different from the hierarchical structure of the organization - the micro level segment. Socioeconomic security of the highest value of the hierarchy is an array of criteria and points that ensure the freedom of the country's economy, its strength and stability, the capacity for constant renewal and selfimprovement. Socioeconomic security of any country is an important high-quality feature of the financial and economic system of the state, which determines its ability to maintain the normal circumstances of life of the population, to ensure the provision of resources for the establishment of the economy, and, in addition, to ensure the national and state interests. Social and economic security guarantees stable financial and economic growth, sufficient provision of social needs, effective management, protection of financial and economic interests at the state and global levels. Socioeconomic security of the lowest value of the hierarchy (enterprise) - a provision of its security from the adverse effects of external and internal hazards, destabilizing moments, which guarantees the stable implementation of financial and economic interests and goals of the work.

Аннотащия. В финансово-экономической макросистеме смешиваются различные иерархические структуры: функциональные, отраслевые, территориальные. Ее иерархическая конструкция имеет возможность быть отличной от иерархической структуры организации - сигмента микроуровня. Социально-экономическая защищенность самого высочайшего значения иерархии - это массив критериев и моментов, обеспечивающих свободу экономики страны, ее прочность и стабильность, дееспособность к неизменному обновлению и самосовершенствованию. Социально-экономическая защищенность всякой страны - важная высококачественная черта финансово-экономической системы государства, определяющая ее дееспособность поддерживать обычные обстоятельства жизнедеятельности населения, гарантировать обеспечение ресурсами становление экономики, и, кроме этого, обеспечивать национально-государственные интересы. Социально-экономическая защищенность гарантирует стойкий финансово-экономический подъем, достаточное обеспечение социальных запросов, действенное управление, защиту финансово-экономических интересов на государственном и глобальном уровнях. Социально- 
экономическая защищенность низшего значения иерархии (предприятия) - это положение его безопасности от неблагоприятного воздействия наружных и внутренних опасностей, дестабилизирующих моментов, при котором гарантируется стойкое осуществление финансово-экономических интересов и целей работы.

Keywords: socio-economic security, the government, society, enterprise, employee, threat, security, interests, economics, analysis, system.

Ключевые слова: социально-экономическая защищенность, государство, общество, предприятие, работник, угроза, защищенность, интересы, экономика, анализ, система.

Security, the reliability of any system can be determined by the stability of the most unreliable part of the security system. As a result, it is methodologically sufficient to have an accurate idea of the system itself, and, in addition, about the tools that would provide an opportunity to qualify the position of its components (links) and find more unreliable and vulnerable ones. The financial and economic system of the macro-level-nonhierarchic system with horizontal connections between single-level components, the role of which is essential. Under the hierarchical structure refers to the design of a complex system in which there are a large number of items of its components into subsets and components of different values, is able to regulate itself and the associated multilayered relations of subordination of subsystems to the lower values of the subsystems of the large values of $[1$, p. 88; 2].

For a set of processes of forming the self - organization-process during which the organization of dynamic system is formed, reproduced or improved is peculiar. If structural changes occur in the system, they have every chance to give rise to a certain kind of external perimeter effects, called synergetic, cooperative effects. The main feature of these effects is the order, purposefulness of the system behaviour with conditional chaotic behaviour of its individual components (subsystems). For developing systems, on the one hand, the stability of the structure, and on the other - the loss of resistance, the destruction of one structure and the creation of another stable structure [3, p. 15; 4, p. 83]. As a result, the process of formation of the system has the ability to be represented as the sequence of the evolutionary configuration of its States inside the cycle with a jump-like transition at the end of the cycle to another high-quality basis, which means the beginning of the next cycle (Figure 1.). It is significant that a hyperstable system is not capable of development, because it extinguishes all possible deviations from its own steady state. As a result, the system is obliged to lose stability for a certain time in order to become a transition to a fundamentally new position. The consequence of repeated formation (with a jump at the end of the cycle to a fundamentally new level) is considered irreversibility, which consists in the impossibility of the transition from the newly formed structure to the previous destroyed structure. Thus, irreversibility, stability and loss of firmness are considered to be features of any evolving system [5].

The study of the stability of balanced conclusions of models of developing socio-economic processes in relation to suitable disturbances and in relation to unplanned changes in the management regime should lead to the development of topical applications to prevent the resulting inconsistency in the structure of the system under consideration and the determination of the stage of the system's penetration into the critical segment [6, p. 198]. 


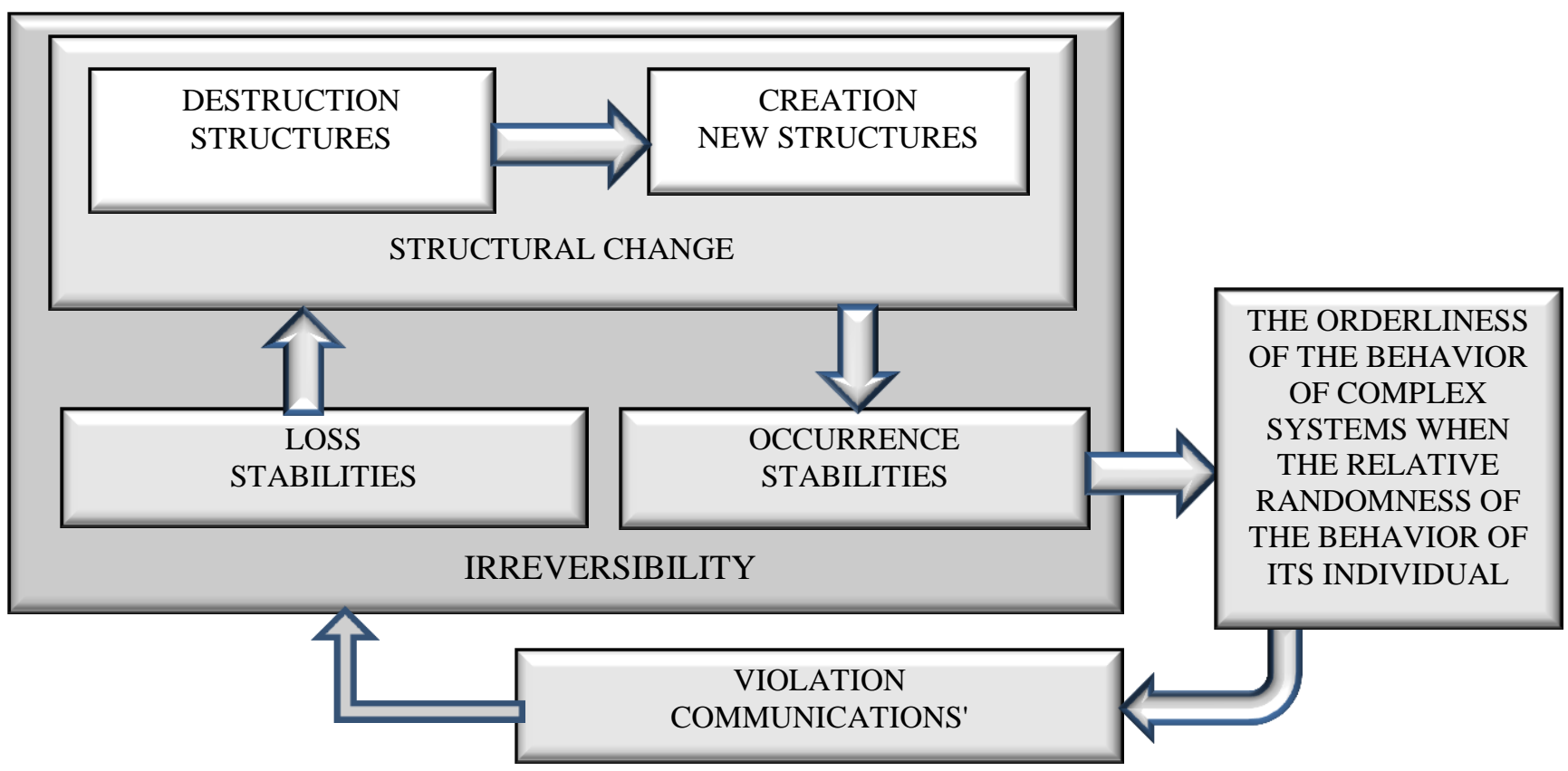

Figure 1. The concept of cyclic development system (Note-author's development)

The proposal for structural stability (rudeness, typicality) of the model appeared in connection with the analysis of mathematical models of radio systems A. A. Andronov and L. S. Pontryagin and had a significant development. The meaning of the idea lies in the following. In mathematical modelling of various phenomena, the characteristics of the equations are understood with finite precision at a time when the equations themselves are considered approximate. In consequence of this force, so that the mathematical model described by equations, high-quality characteristics which do not change with minor perturbations (perturbation) characteristics [7, p. 107]. Such a situation provides an opportunity to obtain a comprehensive assessment of the impact of cause-andeffect relationships on socio-economic security, which is lacking at the current time [8; 9]. This estimate is in contrast to having a place to be will allow you to obtain a more complete and unbiased characterization of national security. So, for example, for the equation

$$
\dot{x}=x^{2}+\lambda
$$

it is clear that each system adopted at random can relate either to the case $\lambda>0$, or to the case $\lambda<0$.

In the initial case, there is no equilibrium position, in another case - both equilibrium States (points a to $B$ in Figure 2.). System with $\lambda=0$ is logical to consider atypical, or structurally unstable. Due to the fact that such a system appeared in the course of modelling, we assume that some significant factors were either unintended, or the system has some special properties (for example, symmetry) that make it atypical.

With the help of mathematical methods developed methods for simplifying systems of equations. They allow to describe the essence of these phenomena the maximum Prasanna, separating it from the minor and irrelevant details. 


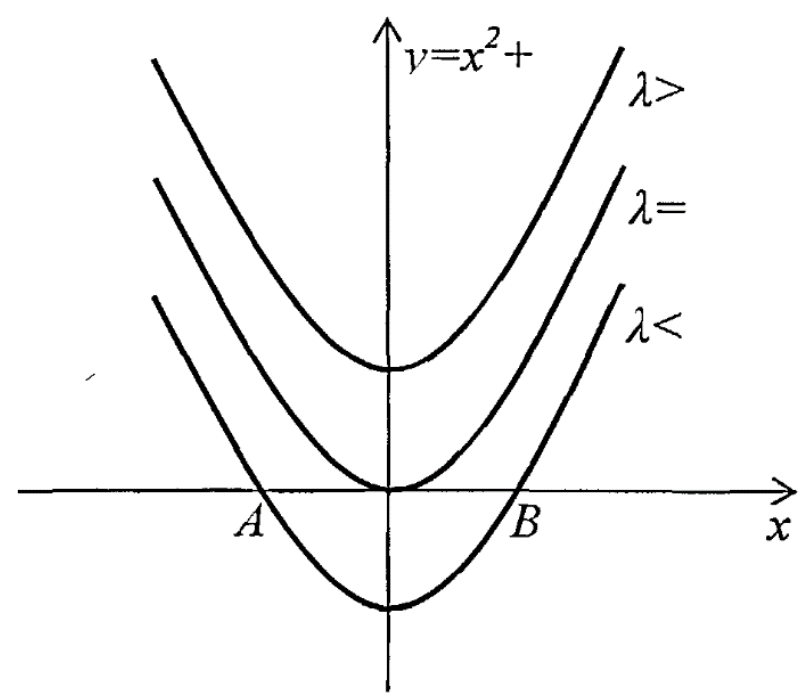

Figure 2. The equilibrium point of the system $\mathrm{x}=\mathrm{x}^{\wedge} 2+\lambda$ at various values of the parameter $\lambda$ (the equilibrium point turns out from the conditions $\mathrm{x} 2+\lambda=0$ ) (Note-author's development)

Formulated requests, which are required to meet the basic models. The key of them is rudeness (the term introduced by A. A. Andronov, the term structural stability introduced by R. Tom). The concept of roughing models plays a significant role and means that all sorts of small refractive errors of the rough model are not able to significantly change the results. Small distortions of the model are understood as:

- increase the number of dynamic variables, or add high-order derivatives, but with small coefficients;

- adding members of the highest degree, but with small coefficients.

Almost all of the phenomena occurring in various fields (physics, chemistry, biology) are described by similar basic models. Their phase portraits are also similar that allows to consider uniting in a huge number of variables, on the 1st look, phenomena. Verbal description of the phenomena is also possible to catch certain analogies but to notice how far they extend in depth, it is impossible [10, p. 274].

The doctrine of bifurcations is close to the concept of structural stability, and its progressive version - the doctrine of catastrophes. This doctrine assesses the question of criteria by which a change in the characteristics of a nonlinear system causes the movement of a point in the phase space that characterizes the position of the system from the area of attraction to the initial position of equilibrium to the area of attraction to another position of equilibrium. The latter is quite fundamentally not only for the analysis of technical systems, but also to understand the persistence of socio-economic processes. As the designation might lead to a test of Gorbachev's perestroika from the standpoint of the doctrine of rearrangements [11, p. 84]. Let the nonlinear system be in steady state. This provision is found to be negative because there is a more preferable stable position of the system within the limits of visibility. Some conclusions of the disaster doctrine in relation to such a system are as follows:

1. The gradual movement of the system towards the best state immediately leads to an increase in negative trends. The displacement speed in the worst direction at a uniform moving towards a better state is increasing. 
2. As you move from the best state to the best state, the system response to changes in its state increases.

3. Maximum resistance is achieved before the worst situation. After passing the maximum resistance, the situation continues to deteriorate.

4. As we approach the worst state on the way of perestroika, the opposition, starting from a certain stage, begins to decrease, and as soon as the worst position is passed, not only the opposition completely disappears, but the system begins to attract to the best state.

5. The amount of offset for the worse, important to switch to one of the best positions comparable to finishing an improvement and increases as you improve the system. A poorly developed system has the ability to move to one of the best positions almost without preparatory displacement to the worse, while the developed system, due to its own resistance, is unable to achieve this gradual, continuous improvement.

6. If the system is obtained immediately, abruptly, and not continuously, move out of a bad stable state is quite good, then it itself will evolve towards a good state [12].

It is possible to recognize that the goals of different values of the financial and economic macro-systems, depending on the location of it in the channel or in the jokers change.

In the channels of the system there is a certain dynamics. It is possible to recognize that for the lower links of the financial and economic hierarchical macrosystem a small dynamics of the whole system makes a small dynamics of the external environment. Thus, the lower links are able to take into account the projected configuration of the external environment, within which they have every chance to try to develop and to guarantee their own socio-economic security.

With the positive dynamics of the external environment, it is necessary to maintain macroeconomic stability. The strength and stability of the country's economy implies the protection of property in all its forms, the creation of favorable conditions and prospects for entrepreneurship, the containment of moments that can destabilize the situation (for example, countering criminal structures in the economy, preventing gaps in the distribution of income, threatening to cause social upheaval, etc.). Figure 1. slam corresponds to the segment of the self-organized state of the system, the areas of jokers-the state of loss of durability, structural adjustments and resistance recovery.

However, not every time the maintenance of macroeconomic stability will ensure the achievement of the established goals. This happens when there is an awareness that the design taking place does not give the correct organization of the system. If the internal environment of the system is correctly organized, the system adapts to the external environment and achieves the set goals, the circumstances of which determines the external environment. The internal environment of the system must be organized in such a way that the configuration of the external environment does not affect the invariance of the relationship between the system and its goals. The desire to preserve invariance gives rise to a structural configuration. In the financial and economic system, the capacity for self-development is obliged to indicate the creation of a suitable climate for investment and innovation, long-term modernization of production structures, an increase in the educational, professional and cultural basis of employees. This is an aspect of the resilience and selfpreservation of the country's economy.

Due to the fact that in a hierarchical system, the share of rights and obligations to make conclusions is entrusted to the lower levels, then, having turned into a relatively Autonomous system signature, this link acquires personal interests, which have all chances not to coincide with the interests of the management of the system. However, when the financial and economic macrosystem is in line, it can not be absolute multidirectional goals, because the goals of the micro level are limited or cut off the external environment (macro). As a result, it is considered that the hierarchical system of management is associated with the probabilistic nature of the financial and 
economic system and presents an opportunity to force small differences of intent within the boundaries of the individual links of the economy. In this case, the provision of social and economic protection of the state can be supported by all levels and structures of the economy.

Measures of financial and economic incentives are used to eliminate motivated contradictions in the economy. They have every chance to relate to issues related to financial and economic education of employees, moral incentives, legal tasks, etc., which are ultimately focused on the grouping of their own, collective and national interests in the economy.

\section{References:}

1. Chernavsky, D. S. (2004). Synergetics and Information: Dynamic Information Theory. M.: Editorial URSS, 287.

2. Krasnova, N. A. (2013). Innovations in economic theories of different schools. Economics and management of innovative technologies, (12). Access mode: http://ekonomika.snauka.ru/2013/12/3476 (date of circulation on 26.05.2017).

3. Pazdnikova, N. P. (2016). Security of program-targeted management of regional socioeconomic systems. Bulletin of the Samara State University of Economics, (1), 14-21.

4. J, B. E., \& Jonathan, O. (2013). Inequality and unsustainable growth: two sides of the same coin. Bulletin of International Organizations: Education, Science, New Economy, 8 (4).

5. Shvayba, D. N. (2017). Problems of coordinating goals and vital interests while ensuring social and economic security. Science and Technics, 16 (6), 526-531.

6. Lebedev, V. V. (1997). Mathematical modeling of socio-economic processes. Moscow: Izograf, 224.

7. Malinetsky, G. G. (2000). Chaos. Structures. Computational experiment: introduction to nonlinear dynamics. Moscow: Editorial URSS, 253.

8. Reznikov, A. F., Tverdokhodebov, V. A., \& Ivashchenko, V. A. and etc. (2013). Human. A machine. Wednesday. Saratov: Publishing Center Science, 195.

9. Yandybaeva, N. V., \& Kushnikov, V. A. (2013). Mathematical model for forecasting the indicators of university accreditation. Management of large systems: Sat. tr. Institute of Problems of Management. Ros. acad. sciences. Moscow. (41). 314-343.

10. Malinetsky, G. G., \& Potapov, A. B. (2000). Modern problems of nonlinear dynamics. Moscow: Editorial URSS, 335 p.

11. Arnold, V. I. (2004). The theory of catastrophes. Moscow: Editorial URSS, 126.

12. Shvaiba, D. N. (2018). An integral element of protection from challenges and threats: the main criteria for socio-economic security in the context of Belarus' national security. Belaruskaya dumka, (2). 48-54.

\section{Список литературы:}

1. Чернавский Д. С. Синергетика и информация: динамическая теория информации. М.: Едиториал УРСС, 2004. 287 с.

2. Краснова Н. А. Инновации в экономических теориях разных школ // Экономика и менеджмент инновационных технологий. 2013. № 12. Режим доступа: http://ekonomika.snauka.ru/2013/12/3476 (дата обращения 26.05.2017).

3. Паздникова Н. П. Безопасность программно-целевого управления региональными социально-экономическими системами // Вестник Самарского государственного экономического университета. 2016. № 1. С. 14-21. 
4. Берг Э. Дж., Остри Дж. Неравенство и неустойчивый рост: две стороны одной медали // Вестник международной организации: образование, наука, новая экономика. 2013. Т. 8. №4. C. 77-99.

5. Швайба Д. Н. Проблемы согласования целей и жизненных интересов при обеспечении социально-экономической безопасности // Наука и техника. 2017. Т. 16. №. 6. С. 526-531.

6. Лебедев В. В. Математическое моделирование социально-экономических процессов. М.: Изограф, 1997. 224 с.

7. Малинецкий Г. Г. Хаос. Структуры. Вычислительный эксперимент: введение в нелинейную динамику. М.: Едиториал УРСС, 2000. 253 с.

8. Резников А. Ф., Тверадохеебов В. А., Иващенко В. А. и др. Человек. Машина. Среда. Саратов: Издательский центр Наука, 2013. 195 с.

9. Яндыбаева Н. В., Кушников В. А. Математическая модель для прогнозирования показателей аккредитации вуза // Управление большими системами: сб. тр. Ин-т проблем упр. Рос. акад. наук. М., 2013. Вып. 41. С. 314-343.

10. Малинецкий Г. Г., Потапов А. Б. Современные проблемы нелинейной динамики. М.: Эдиториал УРСС, 2000. 335 с.

11. Арнольд В. И. Теория катастроф. М.: Едиториал УРСС, 2004. 126 с.

12. Швайба Д. Н. Неотъемлемый элемент защиты от вызовов и угроз: основные критерии социально-экономической безопасности в контексте национальной безопасности Беларуси // Беларуская думка. 2018. № 2. С. 48-54.

Работа поступила

в редакцию 22.04.2018 2.
Принята к публикацчии 27.04.2018 2.

Cite as (APA):

Shvaiba, D. (2018). Structural stability and socio-economic security of the hierarchical system. Bulletin of Science and Practice, 4(6), 233-239.

\section{Ссылка для цичтирования:}

Shvaiba D. Structural stability and socio-economic security of the hierarchical system // Бюллетень науки и практики. 2018. Т. 4. №6. С. 233-239. Режим доступа: http://www.bulletennauki.com/shvaiba-d-n-2018 (дата обращения 15.06.2018). 